\title{
Reproductive Effects Of human Interferon-Alpha-2b Administration on Male Albino Mice Testes.An Experimental Study.
}

\author{
Nabil Abdel Mageed *, Ehsan Hassan **, Azza Hegazy **, Nagwa M. Abdel \\ Wahab *** and Sohir A. Ismail **** \\ Dermatology Department *, Pathology Department**, Public Health \& Biostatistics \\ Department $* * * *$ and Internal Medicine Department**** \\ National Hepatology and Tropical Medicine Research Institute (NHTMRI)
}

\begin{abstract}
Background: Recombinant human interferon alpha (rh-IFN- $\alpha$ ) is used therapeutically in malignant disorders and chronic hepatitis. The phenotypic effects of this drug at the structural levels on testicular tissue were hardly ever addressed. Hence, this work was designed in adult male albino mice to study the phenotypic effects of rh-INF- $\alpha-2 b$ on testicular tissue as well as assessing its effects on serum testosterone and gonadotropins levels.

Objective: This research was planned to through light on the effects of interferon-alpha$2 b$ (IFN-alpha-2b) on the hypothalamic-pituitary-testicular (HPT) axis of the adult male albino mice.

Design: Experimental study.

Setting: National Hepatology and Tropical Medicine Research Institute (NHTMRI). The study was conducted from November (2004) to February (2005).

Materials and methods: Thirty sexually mature male mice were divided into three groups (10 mice in each group), namely: the control, the experimental and the recovery groups. Mice in the experimental and recovery groups were administered recombinant human interferon alpha intraperitoneally at a dose of $3000 \mathrm{U} /$ mouse weekly for 12 weeks in a volume of 1.0-microliter isotonic normal saline, then animals in the recovery group were left to recover for a further period of two months. At the end of the experiment, serum concentrations of gonadotropins and testosterone were measured and then all animals were then sacrificed to study histopathologically the possible effects of interferon on the testicular tissue.

Results: rh-IFN- $\alpha-2 b$ induced remarkable decline in the serum levels of both follicle stimulating hormone (FSH) and luteinizing hormone ( $\mathrm{LH})$ in mice of the experimental group compared to the corresponding control and mice of recovery group. At the same time, testosterone was moderately increased in the experimental group, and then returned to its normal levels within 2 months after cessation of treatment. Histopathologically, in the experimental group, there were focal thickening of the basement membrane, degenerative changes and clumping of the germinal epithelial cells in the center of seminiferous tubules, partial desquamation of the germinal epithelium from basement membrane, reduction in the germ cell height, partial arrest of maturation and increased number of Sertoli cells. Increased number of Leydig's cells and hypervascularity were detected in the interstitial spaces. In the recovery group, there was lessening of the germ cell hypoplasia manifested by restoration of spermatogenic cells and accidental disruption in the basement membrane. Most of the spermatogenic and Sertoli cells restored their polarity, height and maturation.

Conclusion: our results suggest that rh-INF- $\alpha-2 b$ temporally affects the hypothalamicpituitary-testicular axis (HPT), both centrally and peripherally (at the testicular level), through the lessening of FSH, LH, raise of testosterone serum levels and direct phenotypic effect on the testicular tissue.
\end{abstract}




\section{Introduction}

Interferons (IFNs) are potent biological response modifiers. In addition to their antiviral activity, IFNs exert various biological effects, including inhibition of cell growth, activation of the immune system and induction of messenger RNA (mRNA) synthesis of various genes (Kalvakolanu and Borden, 1996). Three major classes of IFNs have been identified. The leukocyte IFNs are designated IFN $\alpha$ and IFN $\gamma$, fibroblast IFN is designated IFNß, and it has an effect on reproductive functions. Treatment of mice with IFN- $\gamma$ results in altered germinal epithelium and decreases spermatogenesis (Natwar et al, 1995 and Bussiere et al., 1996). Male mice that are transgenic for IFNs display alteration of the spermatogenic process and became sterile (Hekman et al., 1988 and Iwakura et al., 1988). IFN gamma also inhibits gonadal steroidogenesis in both vivo and in vitro (Orava et al., 1985a, b, Orava et al., 1989 and Meikle et al., 1992). However, the mechanism by which the INF- $\gamma$ inhibits Leydig's cells steroidogenesis remains unclear. In cultured cells, the somatic epithelial Sertoli cells and the peritubular myoid cells, as well as gem cells produce IFN $\alpha$. In contrast, IFN- $\gamma$ has been shown to be produced by early spermatids but not somatic cells (Dejucq et al., 1995). Mammalian sperm cell has expression of IFN-alpha and IFN-gamma receptors, which seem to develop during spermatogenesis in the testes. These findings may have implications in male infertility and antisperm contraceptive vaccine development (Naz et al., 2000). Targeted gene mutagenesis studies suggest that these IFNs can alter the development of testicular germ cells. In transgenic mice overexpressing either the IFN $\alpha$ or IFNß gene, the process of normal germ cell development (spermatogenesis) is disrupted with concomitant destruction of germ cells (Hekman et al., 1988 and Iwakura et $a l ., 1988)$. IFN- $\alpha$ administration in healthy men reduced serum concentration of both testosterone and free androgen index (Corssmit et al., 2000). Natwar et al. (1995) noticed that IFN $-\gamma$ induced pronounced deleterious effect on the testicular tissue of rats leading to desquamation of the germinal epithelium, reduction in the germinal cell height and tubular diameter and significant decrease in the number of Sertoli cells.

Whereas the effects of interferons on a large number of biological systems have been thoroughly investigated, yet few controlled studies regarding their effects on the reproductive system are available. Moreover, most of the work in literature, concerning effects of interferons addresses the hormonal, and more generally the homeostatic effects of these drugs. The phenotypic effects of these drugs at the structural levels on testicular tissue were seldom addressed. Hence, this work was designed in adult male albino mice to study the phenotypic effects of rh-INF- $\alpha$ $2 \mathrm{~b}$ on testicular tissue as well as assessing its effects on serum testosterone and gonadotropins levels.

\section{Materials and methods}

The study was conducted from November 2004 to February 2005 in National Hepatology and Tropical Medicine Research Institute (NHTMRI).

Study Animals: This study was performed on thirty sexually mature male Swiss albino mice. They were about $6-7$ weeks old, average weight $20-25$ grams. Animals were allowed to stabilize for a minimum of 6 days within our facility before treatment. Food and water were allowed ad libitum and they were housed at room temperature. The animals were randomly divided into three groups; each comprised 10 mice, the control group, the experimental and the recovery groups.

1 -The control group.

2-The experimental group were injected with interferon alpha- $2 b$.

3-The recovery group received the same regime as experimental group and was then left for further two months after drug cessation to study the reversibility of the possible testicular effects induced by interferon.

Study drug :( Interferon) Interferonalpha-2b was purchased from Nile Company for pharmaceuticals and chemical industries. 
Mode of administration: The drug was administered once weekly for 12 injections. Each mouse in the experimental and recovery groups received 3000 units weekly via intraperitoneal injection, in a volume of 1.0 micro liter isotonic normal saline according to Maria et al. (2002).

Hormonal assay: Serum testosterone and gonadotropins (FSH \& LH) were detected trice: first prior to study, second at the end of the study and finally at the end of the recovery period. Blood samples were drawn via an indwelling cannula in the tail artery. Serum was separated and stored at $20^{\circ} \mathrm{C}$ until estimation. Serum levels of testosterone were measured by radioimmunoassay as described by Abraham (1975). The levels of FSH \& LH in the serum were also determined using radioimmunoassay as previously described by Billiar et al. (1989).

Light microscopic study: At the end of the trial, all animals were sacrificed to study the possible effects of interferon on testicular tissue. The testes were removed, fixed in bouin's fluid and processed for paraffin blocks. Sections were cut at a thickness of about $3 \mu$. The sections were mounted on slides and stained with Hematoxylin and Eosin. It is noteworthy to mention that the same technique of fixation of the specimens was followed strictly to ensure avoidance of fixation artifacts that might interfere with the histological appearance of examined sections.

Image analysis: average spermatogenic cell count per seminiferous tubule, average tubular dimensions and average interstitial cell of Leydig per interstitial space in all studied groups were detected using a Quantimet 500+ image analyzer (Leica, UK). Sections or areas with artifacts were omitted from such analysis. A minimum of 20 seminiferous tubule and 20 interstitial spaces were examined for each testis.

Statistical analysis: Data were collected, coded and analyzed by statistical package for Social Science (SPSS) software version (12) under windows XP and EpiInfo version 6 program. For each measured data (hormonal profile data, average dimensions of seminiferous tubules, average number of interstitial cells of Leydig per interstitial space and average number of spermatogenic cells per seminiferous tubule), means, standard deviations and standard errors were obtained from results of the studied groups. Analytical and statistical comparative study of the recorded data were done using independent groups't-test for samples which used for comparison of means of the matching variables; one tailed test for significance was used. Pvalue $<0.05$ was considered statistically significant and a $\mathrm{p}$-value $<0.01$ was considered statistically highly significant (Bryman and Cramer, 1999).

\section{Results}

Hormonal profile:

Serum Testosterone level (Table 1):

The concentration of serum testosterone level showed a remarkable increase in the experimental group compared to the corresponding control by the end of the experimental period $(0.71 \pm 0.199$ compared to $0.503 \pm 0.176)$. The difference between these two groups was about to reach the level of statistical significance $(\mathrm{p}=0.0115)$. This was followed by a decline at the end of the recovery period, yet it failed to reach the corresponding control level. Such change was not statistically significant $(\mathrm{p}=$ 0.4925).

\section{Serum FSH level (Table 1):}

The concentration of serum follicle stimulating hormone (FSH) level showed a remarkable decline in the experimental group compared to the corresponding control by the end of the experimental period $(0.50 \pm 0.147$ compared to $17.5 \pm$ 2.003). The difference between these two groups was highly significant $(\mathrm{p}=0.000)$. This was followed by a rise at the end of the recovery period, yet it failed to reach the corresponding control level. Such change was statistically significant $(\mathrm{p}=$ 0.000 ).

\section{Serum LH level (Table 1):}

The concentration of serum luteinizing hormone $(\mathrm{LH})$ in mice of the experimental group showed a remarkable decline in the experimental group comp- 
ared to the corresponding control by the end of the experimental period $(0.100 \pm 0.026$ compared to $7.5 \pm 1.55)$. The difference between these two groups was highly significant $(\mathrm{p}=0.000)$. This was followed by a rise at the end of the recovery period, yet it failed to reach the corresponding control level. Such change was statistically significant $(\mathrm{p}=0.000)$.

Light microscopic study and image analysis:

Control group:

Histological examination of testicular sections of control mice revealed normal appearance of seminiferous tubules with normal interstitial tissue between them and intact abundant interstitial cells of Leydig (Fig.2). The average perimeter, length, width, and diameter of the seminiferous tubules were $6.038 \pm 2.25$, $2.04 \pm 0.99,1.18 \pm 0.31$ and $1.18 \pm 0.31 \mathrm{~mm}$ respectively (Magnification 320X).

Experimental group:

Histological examination of testicular sections of mice in the experimental group, revealed both qualitative and quantitative changes, observed by the end of the experimental period:

\section{Quantitative changes:}

There was mild germ cell hypoplasia and the average number of spermatogenic cells per tubule was much lower compared to corresponding controls $(601.2273$ \pm 301.4512 compared to $950 \pm 25.3$ ). This difference was found to be statistically significant $(\mathrm{p}=0.0151)$ (Table 3$)$.

The average number of interstitial Leydig's cells per interstitial space clearly increased to $20 \pm 12.5$ compared to $16 \pm 11.2$ in corresponding control (Table 4). This difference was not statistically significant $(p=0.29)$. The average diameter of the seminiferous tubules was much lesser compared to corresponding control (1.18 \pm 0.13 compared to $1.59 \pm 0.19)$. This difference was found to be highly statistically significant $(p=0.000)$ (Table 2). This was followed by an increase at the end of the recovery period to nearly reach the corresponding control level $(\mathrm{p}=0.183)$.

\section{Qualitative changes:}

Interferon administration induced deleterious effects on the testicular tissue of mice of the experimental group, in the form of focal thickening of the basement membrane (1/10), degenerative changes and clumping of the germinal epithelial cells in the center of seminiferous tubules (2/10) (Fig. $3 \& 4$ ) partial desquamation of the germinal epithelium from basement membrane (3/10) (Fig. 7 \&8). In addition, there was reduction in the germ cell height (2/10), partial arrest of maturation (3/10) (Fig. 5\&6) and increased number of Sertoli cells $(5 / 10)$. Increased number of Leydig's cells (6/10) (Fig. 9) and hypervascularity $(2 / 10)$ were detected in the interstitial spaces. There was a significant difference in the tubular diameter between the experimental and corresponding control group.

\section{Recovery group:}

\section{Quantitative changes:}

lessening of the germ cell hypoplasia manifested by restoration of some spermatogenic cells within the tubules, however partial maturation arrest was still observed in many tubules. The average number of spermatogenic cells per tubule was still lower compared to corresponding controls $(635.5 \pm 301.4512$ compared to $950 \pm 25.3)$. This difference was found to be statistically significant $(\mathrm{p}=0.0151)$ (Table 3). The average number of Leydig's cells per tubule was $18 \pm 12.2$ compared to $16 \pm 11.2$ in corresponding control (Table 4). This difference was not statistically significant $(\mathrm{p}=0.59)$.

\section{Qualitative changes:}

Although basement membrane defects were less than the experimental group, yet focal disrupted areas could still be observed in some tubules (1/10). Most of the spermatogenic and Sertoli cells restored their polarity, height and maturation (Fig. 10). Leydig's cells restored their normal configuration and number. Their was no significant differences between tubular diameter and germ cell height in comparison with the corresponding control group. 
Table (1): Values of FSH, LH, and testosterone among the experimental group (group II) and the recovery group (group III).

\begin{tabular}{|c|c|c|c|c|c|c|c|c|c|}
\hline \multirow[b]{2}{*}{ Groups } & \multicolumn{3}{|c|}{ Testosterone (pg/ml) } & \multicolumn{3}{|c|}{ FSH (mIU/ml) } & \multicolumn{3}{|c|}{ LH (mIU/ml) } \\
\hline & Mean \pm SD & SE & $\begin{array}{l}\text { P value } \\
\text { (Two- } \\
\text { tailed) }\end{array}$ & Mean \pm SD & SE & $\begin{array}{l}\mathrm{P} \text { value } \\
\text { (Two- } \\
\text { tailed) }\end{array}$ & Mean \pm SD & SE & $\begin{array}{l}\text { P value } \\
\text { (Two- } \\
\text { tailed) }\end{array}$ \\
\hline $\begin{array}{c}\text { Experimental } \\
\text { Corresponding control }\end{array}$ & $\begin{array}{l}0.71 \pm 0.199 \\
0.503 \pm 0.176 \\
\end{array}$ & $\begin{array}{l}0.063 \\
0.056 \\
\end{array}$ & $0.023 *$ & $\begin{array}{l}0.50 \pm 0.147 \\
17.5 \pm 2.003\end{array}$ & $\begin{array}{l}0.047 \\
0.634 \\
\end{array}$ & $0.000 * *$ & $\begin{array}{l}0.100 \pm 0.026 \\
7.5 \pm 1.55\end{array}$ & $\begin{array}{l}0.01 \\
0.49 \\
\end{array}$ & $0.000 * *$ \\
\hline $\begin{array}{c}\text { Recovery } \\
\text { Corresponding control }\end{array}$ & $\begin{array}{l}0.5015 \pm 0.177 \\
0.503 \pm 0.176\end{array}$ & $\begin{array}{l}0.056 \\
0.056 \\
\end{array}$ & 0.985 & $\begin{array}{l}1.4 \pm 0.29 \\
17.5 \pm 2.003\end{array}$ & $\begin{array}{l}0.092 \\
0.634\end{array}$ & $0.000 * *$ & $\begin{array}{l}2.8 \pm 0.84 \\
7.5 \pm 1.55\end{array}$ & $\begin{array}{l}0.27 \\
0.49 \\
\end{array}$ & $0.000 * *$ \\
\hline
\end{tabular}

$$
\begin{aligned}
& \mathrm{SD}=\text { Standard Deviation } \\
& \mathrm{SE}=\text { Standard Error } \\
& *=\text { Significant (two tailed) at } \mathrm{P}<0.05 \\
& * *=\text { Highly Significant (two tailed) at } \mathrm{P}<0.01
\end{aligned}
$$

\begin{tabular}{|c|c|c|c|c|c|c|c|c|c|c|c|}
\hline \multirow[t]{2}{*}{ Groups } & \multicolumn{2}{|c|}{ Perimeter (mm) } & \multicolumn{3}{|c|}{ Length (mm) } & \multicolumn{3}{|c|}{ Width (mm) } & \multicolumn{3}{|c|}{ Diameter (mm) } \\
\hline & Mean \pm SD SE & $\begin{array}{c}\mathrm{P} \\
\text { value } \\
\text { (Two- } \\
\text { tailed) }\end{array}$ & Mean \pm SD & SE & $\begin{array}{c}\mathrm{P} \\
\text { value } \\
\text { (Two- } \\
\text { tailed) }\end{array}$ & Mean \pm SD & SE & $\begin{array}{l}\text { P value } \\
\text { (Two- } \\
\text { tailed) }\end{array}$ & Mean \pm SD & SE & $\begin{array}{l}\text { P value } \\
\text { (Two- } \\
\text { tailed) }\end{array}$ \\
\hline Experimental & $\begin{array}{ll}6.038 & 0.218 \\
\pm 2.25 & \end{array}$ & & $\begin{array}{l}2.40 \\
\pm 0.99\end{array}$ & 0.095 & & $\begin{array}{l}1.18 \\
\pm 0.31\end{array}$ & & & $\begin{array}{l}1.18 \\
\pm 0.31\end{array}$ & 0.03 & \\
\hline $\begin{array}{l}\text { Corresponding } \\
\text { control }\end{array}$ & $\begin{array}{ll}5.53 & 0.299 \\
\pm 0.95 & \end{array}$ & 0.18 & $\begin{array}{l}2.07 \\
\pm 0.04\end{array}$ & 0.127 & $0.048 *$ & $\begin{array}{l}1.31 \\
\pm 0.215\end{array}$ & 0.07 & 0.206 & $\begin{array}{l}1.59 \\
\pm 0.194\end{array}$ & 0.06 & $0.000 * *$ \\
\hline Recovery & $\begin{array}{l}5.11 \\
\pm 2.35\end{array}$ & & $\begin{array}{l}1.89 \\
\pm 0.84\end{array}$ & 0.106 & & $\begin{array}{l}1.05 \\
\pm 0.33\end{array}$ & 0.04 & & $\begin{array}{l}1.44 \\
\pm 0.51\end{array}$ & 0.06 & \\
\hline $\begin{array}{l}\text { Corresponding } \\
\text { control }\end{array}$ & $\begin{array}{l}5.53 \\
\pm 0.95\end{array}$ & 0.586 & $\begin{array}{l}2.07 \\
\pm 0.4\end{array}$ & 0.127 & 0.284 & $\begin{array}{l}1.31 \\
\pm 0.215\end{array}$ & 0.07 & $0.019 *$ & $\begin{array}{l}1.59 \\
\pm 0.194\end{array}$ & 0.06 & $0 . .366$ \\
\hline
\end{tabular}

Table (2): Average dimensions of seminiferous tubules in the testes of male albino mice in the experimental and recovery groups compared to the corresponding controls (Magnification 320X).

* = Significant (two tailed) at $\mathrm{P}<0.05$

$* *=$ Highly Significant (two tailed) at $\mathrm{P}<0.01$

Table (3): Average number of spermatogenic cells per seminiferous tubule in the testes of male albino mice in the experimental and recovery groups compared to the corresponding controls.

\begin{tabular}{|l|l|l|}
\hline Groups & $\begin{array}{l}\text { Average number of spermatogenic cells / tubule } \\
\text { Mean } \pm \text { SD }\end{array}$ & $\begin{array}{l}\text { P value } \\
\text { (Two tailed) }\end{array}$ \\
\hline Experimental & $601.2273 \pm 301.45124$ & $0.0302^{*}$ \\
Corresponding control & $950 \pm 25.3$ & $0.022^{*}$ \\
\hline Recovery & $635.5 \pm 241.79975$ & \\
Corresponding control & $950 \pm 25.3$ & \\
\hline
\end{tabular}

* Significant (two-tailed) at $\mathrm{P}<0.05$

Table (4): Average number of interstitial cells of Leydig per interstitial space in the testes of male albino mice in the experimental and recovery groups compared to the corresponding controls.

\begin{tabular}{|l|l|l|}
\hline Groups & $\begin{array}{l}\text { Average number of Leydig's cells } \\
\text { / space } \\
\text { Mean } \pm \text { SD }\end{array}$ & $\begin{array}{l}\text { P value } \\
\text { (Two tailed) }\end{array}$ \\
\hline Experimental & $20 \pm 12.5$ & 0.29 \\
Corresponding control & $16 \pm 11.2$ & 0.59 \\
\hline Recovery & $18 \pm 12.2$ & \\
Corresponding control & $16 \pm 11.2$ & \\
\hline
\end{tabular}

$\mathrm{SD}=$ Standard Deviation 


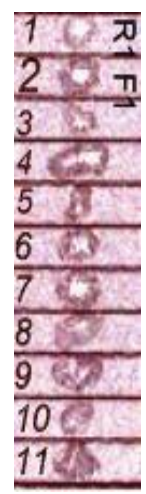

Fig.1: A magnified sample of image analysis of the first field of slid 1 in the recovery group.

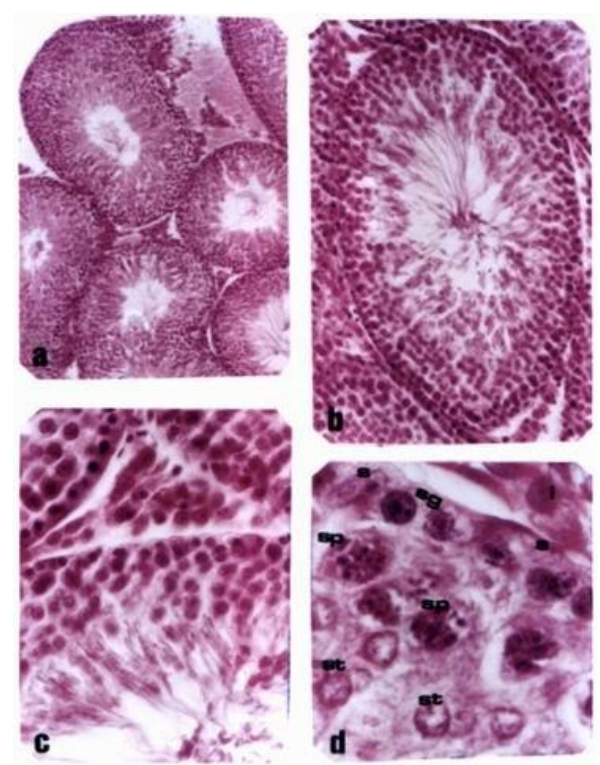

Fig 2: Photomicrographs of $\mathrm{Hx}$ and $\mathrm{E}$ stained sections of testes of control male albino mice showing:

a) Normal structure of seminiferous tubules with normal interstitial spacing between them (x 100)

b) Normal appearance of seminiferous epithelium at different stages of the cycle (x 200)

c) Normal cellular and vascular appearance of interstitial tissue enclosed between the seminiferous tubules with intactness of the basement membrane (x400)

d) Regularity of the chromatin pattern of spermatogenic cells with more or less vesicular nuclei (x 1000). 


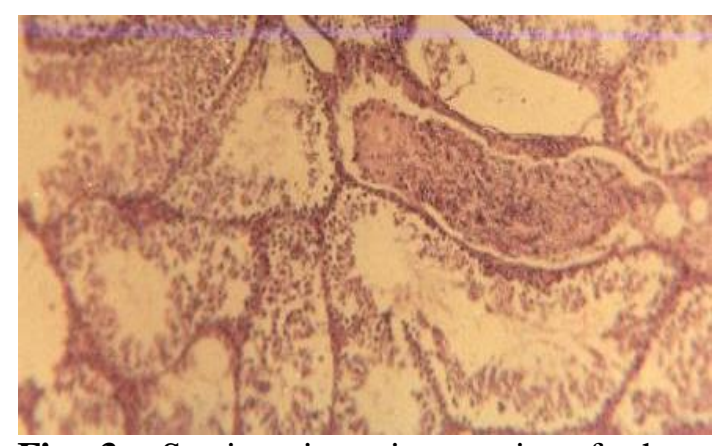

Fig 3: Section in mice testis of the experimental group showing degenerative changes and clumping of germ cells in the center of the seminiferous tubules $(\mathrm{H} \& \mathrm{E}$ $\mathrm{x} 200)$.

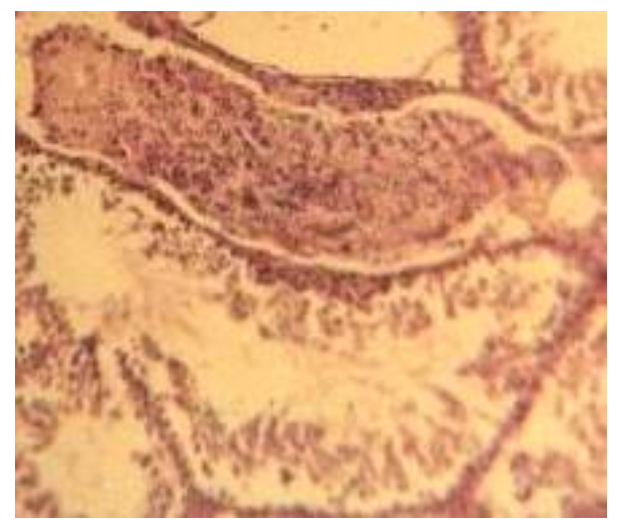

Fig 4: A higher magnification of Fig 3.

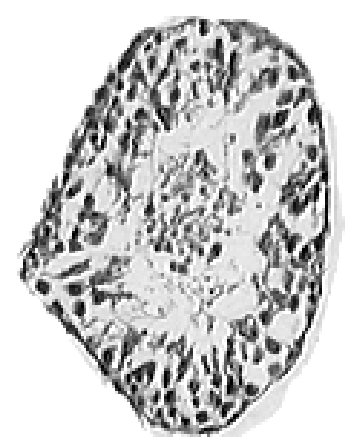

Fig 6: Section in mice seminiferous tubule of the experimental group showing germ cell hypoplasia, arrest of maturation and clumping of the spermatogenic cells in the center of the tubules (H\&E x200).

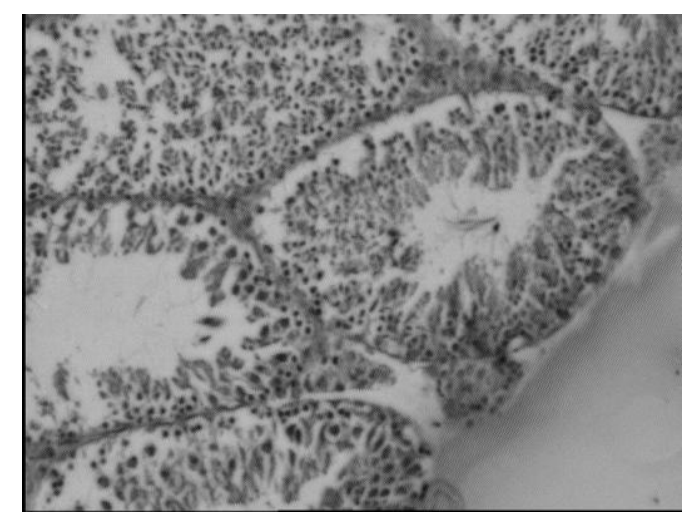

Fig 7: Section in mice testis of the experimental group showing desquamation of the germinal epithelium from the basement membrane (H\&E x200).

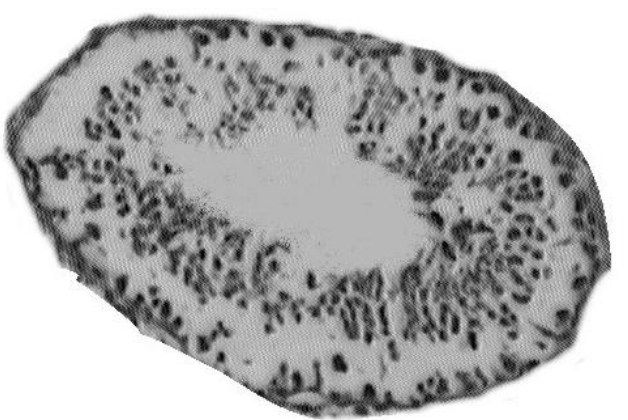

Fig 8: Section in mice seminiferous tubule of the experimental group showing desquamation of the germinal epithelium from the basement membrane (H\&E x200). 


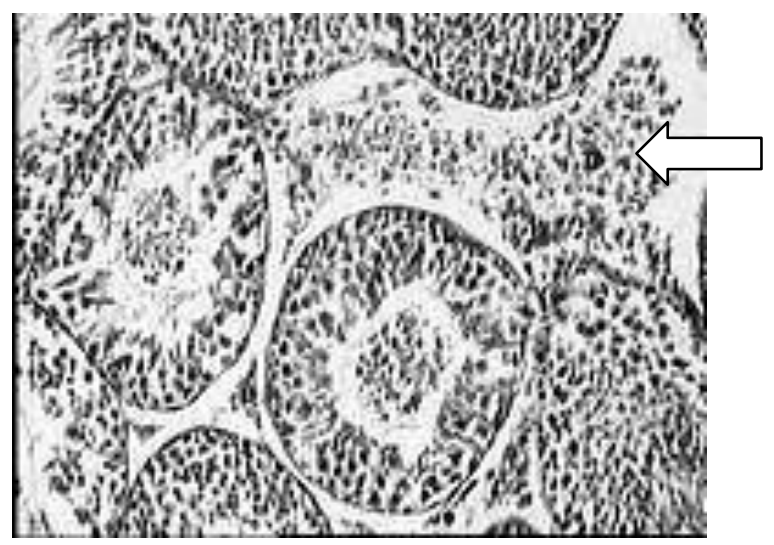

Fig 9: Section in mice testis of the experimental group showing increased no. of Leydig's cells (H\&E x200).

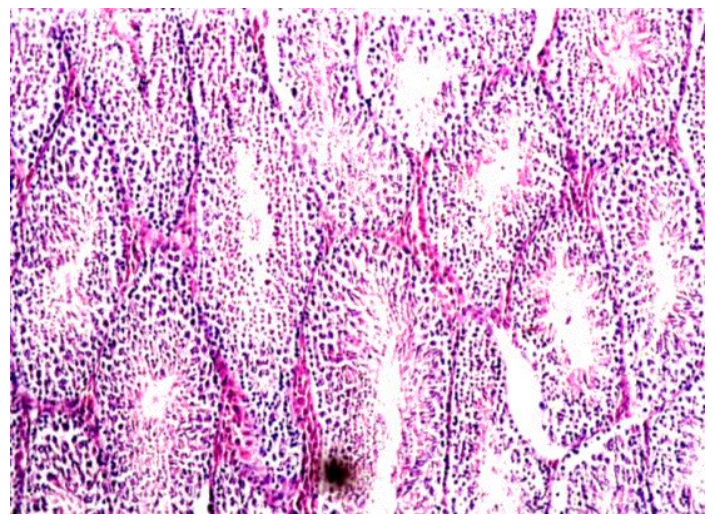

Fig 10: Section in mice testis of the recovery group Showing restoration of configuration and structure of seminiferous tubules and interstitial tissue (H\&E x200).

\section{Discussion}

Testicular cytokines represent recently identified local signaling molecules that apparently affect spermatogenesis in a legend-specific manner. Interferons (IFNs) are a family of secreted polypeptides that are divided into three main categories: IFN $\alpha$ and IFNß (type I IFNs), initially described as the product of virus-infected leukocytes and fibroblasts, and IFN gamma $(\gamma)$ (type II IFN), produced when lymphocytes and natural killer cells are stimulated by antigenic or mitogenic substances (Blakwill, 1989). Mammalian cells into which the human interferon beta gene has been introduced produce interferon beta-1a. Interferon beta- $1 \mathrm{~b}$ is made by bacterial fermentation of a strain of Escherichia coli that is a genetically engineered plasmid containing the gene for human interferon beta (Healthdigest.org, 2003). The mammalian sperm cell has expression of IFN-alpha and IFN-gamma receptors, which seem to develop during spermatogenesis in the testes (Naz et al, 2000). In cultured cells, the somatic epithelial Sertoli cells and the peritubular myoid cells, as well as germ cells produce IFN $\alpha$. In contrast, IFN $\gamma$ has been shown to be produced by early spermatids but not somatic cells (Dejucq et al, 1995). Interferon- $\gamma$ (IFN- $\gamma$ ) is an

immunomodulating cytokine that has profound effects on reproductive function. IFN - $\gamma$ inhibits steroidogenesis both in vivo and in vitro. The mechanism by which IFN - $\gamma$ inhibits Leydig's cell steroidogenesis remains unclear. In 2003 Chen and co-workers proposed that one possible mechanism of inhibition of Leydig's cell steroidogenesis by IFN $-\gamma$, is that it down regulate the expression of glucose transport 8 (GLUT8), which results in decreased glucose uptake by Leydig's cells and inhibition of testosterone production. On the other hand the effect of human gamma interferon on the testicular histology of mice was studied by Natwar et al., 1995, and they found with increasing doses of IFN $-\gamma$ pronounced deleterious effect on the testis leading to desquamation of the germinal epithelium, reduction in the germinal cell height and tubular diameter, significant decrease in the number of Sertoli cells, stage-7 spermatids and stage-16 spermatozoa. Opposing to this, Hibi et al., (2004), confirmed that alpha-interferon might improve testicular spermatogenesis and increase epididymal sperm concentration in the rat. Corssmit et al., (2000), performed a saline-controlled crossover study in six healthy men, sequentially measuring the 
serum concentrations of gonadotropins, testost-erone, the free androgen index and sex hormone-binding globulin (SHBG) after a bolus subcutaneous injection of recombi-nant human interferon alpha and they found that rh-IFN-alpha induced a sustained decrease of both testosterone and free androgen index, whereas concentrations of LH, FSH, and SHBG were not different between the studies, so they concluded that rh-IFN-alpha affects the hypothalamic-pituitary-testicular axis at the testicular level. On contrary to this Barreca et la., (1993) studied the effect of long-term treatment with recombinant interferon-alpha 2b (IFN-alpha 2b) on luteinizing hormone (LH), testosterone, free testosterone, and sex hormonebinding globulin (SHBG) in 7 male patients suffering from chronic viral hepatitis and they reported that IFN-alpha $2 b$ was not responsible for any measurable imbalance in male sex hormones. In a therapeutic trial performed on four patients with bilateral mumps orchitis, Erpenbach and Derschum (1991) observed that systemic treatment with interferon-alpha$2 b$ appears to be highly effective in preventing sterility and testicular atrophy in patients with bilateral mumps orchitis. Interferon A has been studied for its effect on fertility in Macaca mulatta (Rhesus monkeys). Non-pregnant rhesus females treated with Roferon-A at doses of 5 and $25 \mathrm{MIU} / \mathrm{kg} /$ day have shown menstrual cycle irregularities, including prolonged or shortened menstrual periods and erratic bleeding; these cycles were considered to be anovulatory on the basis that reduced progesterone levels were noted and that expected increases in preovulatory estrogen and luteinizing hormones were not observed. These monkeys returned to a normal menstrual rhythm following discontinuation of treatment (HIV and Hepatitis.com, (2004). Fujisawa et al., (1998) investigated the role of interferon alpha and gamma in the seminal plasma on spermatogenesis. The levels of interferon alpha and gamma were determined in the seminal plasma of 101 males including normozoospermic, oligozoospermic and azoospermic men. The correlation between such levels and clinical parameter (seminogram and serum hormone levels) was evaluated. The three groups did not differ as to the level of interferon gamma. No significant correlations were observed between the levels of interferon alpha or gamma in seminal plasma and the serum levels of follicle stimulating hormone $(\mathrm{FSH})$, luteinizing hormone (LH), testosterone, prolactin, or estradiol. Theses results suggest that the level of interferon alpha in the seminal plasma may be related to sperm production. Our results are not consistent with that reported by Corssmit et al., (2000) who found that rh-INF-alpha induced a sustained decrease of both testosterone and free androgen index, whereas concentrations of $\mathrm{LH}, \mathrm{FSH}$, and SHBG were not affected in healthy men after a bolus subcutaneous injection of recombinant human interferon alpha. In 1985 a \& b, Orava and co-workers documented that Human leukocyte interferon inhibits human chorionic gonadotropin stimulated testosterone production by porcine Leydig's cells in culture and the site of interferon action on hCG-stimulated testosterone production in primary cultures of porcine Leydig's cells is located distal to cAMP formation. Also in consistent with our results, Hibi et al, 2004 reported that Alpha-IFN might improve testicular spermatogenesis and increase the epididymal sperm concentration in the rat. These promising results with alpha-IFN may pave the way for a new approach to treating male infertility. The present work confirmed that interferon has a stimulant effect on testosterone secretion, yet after cessation of the drug, normal testosterone levels were nearly achieved in recovery group by the end of the recovery period. This increase in testosterone secretion could be mediated either centrally through inhibition of luteinizing hormone $(\mathrm{LH})$ or peripherally through the action of interferon at the testicular level. The significant changes in $\mathrm{LH}$ and $\mathrm{FSH}$ and serum testosterone among the experimental group, could exclude the exclusive peripheral (direct testicular) effect of rhINF- $\alpha-2 b$ on the gametogenic function of the testis in our study. Restoration of normal testosterone levels by the end of the recovery period may point to the 
possibility of a reversible suppressive effect of Alpha-IFN on the level of this hormone.

The effect of interferon on fertility was pronounced and acutely inflicted. Histological sections of animals in the experimental group exhibited both quantitative and qualitative damaging effects. The average number of spermatogenic cells per tubule was much lower compared to corresponding controls. Such change was found to be statistically significant $(\mathrm{p}=0.0151)$. Despite the recovery observed in weaned animals, the average spermatogenic cells number per tubule was still about $2 / 3$ of the normal control counterparts. Such sustained reduction was also statistically significant $(\mathrm{p}=0.011)$. Qualitatively, the toxic effects of interferon on spermatogenic cells in the experimental animals were marked and involved both the spermatogenic cells and the basement membrane. These qualitative damaging impacts of interferon were markedly reduced in the recovery animals as manifested by lessening of the germ cell hypoplasia and accidental disruption in the basement membrane.

Histologically, Leydig cell changes paralleled testosterone level changes in the experimental group. The average number of interstitial Leydig's cells per interstitial space clearly increased to $20 \pm 12.5$ compared to $16 \pm 11.2$ in corresponding Such Leydig's cell changes could explain the early findings of Brown and Dobs (2002), concerning the increase of gonadal steroid and inhibition of hypothalamicpituitary axis since Leydig's cell stimulation causes increase in testosterone production with subsequent release of a negative feedback mechanism on such axis.

The present work emphasizes the transitory adverse effects of interferon on the testis and highlighted such effects on fertility.

\section{Conclusion}

Our results suggest that rh-INF- $\alpha-2 b$ temporally affects the hypothalamicpituitary-testicular axis (HPT) both centrally and peripherally (at the testicular level), through the lessening of $\mathrm{FSH}$, LH, raise of testosterone serum levels and direct phenotypic effect on the testicular tissue.

\section{References}

1. Abraham G.F. (1975): Radioimmunoassay of steroids in biological material. Acta endocrinol. , 7(suppl) 183:191.

2. Barreca T., Picciotto A., Franceschini R., Varagona G., Garibaldi A., Valle F., Cataldi A., D'Agostino, S. and Rolandi E.(1993): Sex hormones and sex hormone-binding globulin in males with chronic viral hepatitis during recombinant interferon-alpha $2 \mathrm{~b}$ therapy. J Interferon Res. 13(3): 209-211.

3. Billiar R.B., Richardson D.W. and Little B. (1989): Escape for chronic estrogenic suppression of ovarian function in the adult Rhesus monkey: evidence for changing sensitivity of gonadotropin secretion to estrogen inhibition. Endocrinology 124:2373.

4. Blakwill F.R. (1989): Interferons. Lancet 1:1060-1063.

5. Brown, T.T. and Dobs, A. (2002): Endocrine effects of marijuana. J. Clin. Pharmacol. Suppl., 42(11): 90-96.

6. Bryman, A. and Cramer, D. (1999): Quantitative data analysis with SPSS for windows. A guide for social scientists. London, Rout Ledge.

7. Bussiere J.L., Hardy LM, Hoberman A.M., Foss J.A. and Christian MS. (1996): Reproductive effects of chronic administration of murine interferongamma. Reprod Toxicol 10:379-391.

8. Chen T., Nagpal M.L. and Lin T. (2003): Expression and regulation of glucose transport 8 in rat leydig cells. J Endocrinol 179(1): 63-72.

9. Corssmit E.P., Endert E., Sauerwein H.P and Romijn J.A. (2000): Acute effects of interferon-alpha administration on testosterone concentrations in healthy men. Eur J Endocrinol. Sep. 143(3): 371 374.

10. Dejucq N., Dugast I., Ruffault A., Meide P.H. and Jegou B. (1995): Interferon- $\alpha$ and $-\gamma$ expression in the rat testis. Endocrinology 136:4925-4931.

11. Erpenbach, K. and Derschum, W. (1991): Systemic alpha-interferon therapy: a possible method for prevention of testicular atrophy and permanent sterility in patients with bilateral mumps orchitis. Urolge A. 30(4): 244-248.

12. Fujisawa M., Fujioka H., Tatsumi N., Inaba Y., Okada H., Arakawa S. and 
Kamidono S. (1998): Levels of interferon alpha and gamma in seminal plasma of normozoospermic, oligozoospermic, and azoospermic men. Arch Androl 40(3): 211-214.

13. Healthdigest.org (2003): Interferon beta1a, Interferon beta-1b

14. Hekman A.C.P., Trapman J., Mulder A.H., van Gaalen J.L. and Zwarthoff E.C. (1988): Interferon expression in the testes of transgenic mice leads to sterility. J Biol Chem 263:12151-12155.

15. Hibi, H., Yokoi, K. and Yamamoto, $M$. (2004): Effects of alpha-interferon on sperm production, concentration, and motility in the rat. PIMD: 9477192 \{PubMed .

16. HIVandHepatitis.com (2004): Hepatitis C Treatment. HIVandHepatitis.com

17. Iwakura Y., Asano M., Nishimune Y. and Kawade Y. (1988): Male sterility of transgenic mice carrying exogenous mouse interferon- $\beta$ gene under the control of the metallothionein enhancer-promoter. EMBO J 7:3757-3762.

18. Kalvakolanu D.V. and Borden E.C. (1996): An overview of the interferon system: signal transduction and mechanism of action. Cancer Invest 14:25-53.

19. Maria de Lujan, Juan P.C., Juan M., Critina C. and Maria T. (2002): The in vivo apoptotic effect of interferon alpha$2 \mathrm{~b}$ on rat preneoplastic liver involves bax protein. Hepatology, 35:824-833.
20. Meikle A.W., Cardoso de Sousa J.C., Dacosta N., Bishop D.K. and Samlowski W.E. (1992): Direct and indirect effects of murine interleukin-2, gamma interferon, and tumor necrosis factor on testosterone synthesis in mouse Leydig cells. J Androl 13:437-443.

21. Natwar R.K., Mann A., Sharma R.K., Aulitzky W. and Frick J. (1995): Effect of human gamma interferon on mice testis: a quantitative analysis of the spermatogenic cells. Acta Eur Fertil 26:45-49

22. Naz R.K., Chauhan S.C. and Rose L.P. (2000): Expression of alpha and gamma interferon receptors in the sperm cell. Mol Reprod Dev 56(2): 189-197.

23. Orava M., Cantell K. and Vihko R. (1985a): Treatment with preparations of human leukocyte interferon decreases serum testosterone concentrations in men. Int J Cancer 38:295-296.

24. Orava M., Cantell K. and Vihko R. (1985b): Human leukocyte interferon inhibits human chorionic gonadotropin stimulated testosterone production by porcine Leydig cells in culture. Biochem Biophys Res Commun 127:809-815.

25. Orava M., Voutilainen R. and Vihko R. (1989): Interferon-gamma inhibits steroidogenesis and accumulation of mRNA of the steroidogenic enzymes $\mathrm{P} 450$ scc and $\mathrm{P} 450 \mathrm{c} 17$ in cultured porcine Leydig cells. Mol Endocrinol 3:887-894. 


\section{تأثثير عقار الاتترفيرون على الإخصاب في فئران التجارب}

نبيل عبد المجيد - إحسان حسن - عزة حجازي- نجوى عبد الوهاب- سهير أحمد إسماعيل المعهد القومي للأمر اض المتوطنة و الكبد

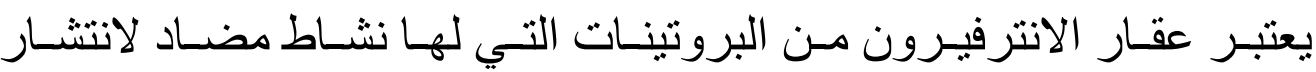

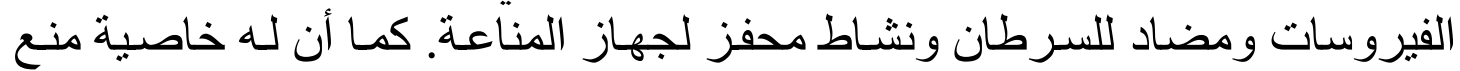

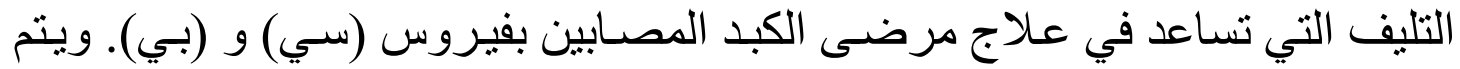

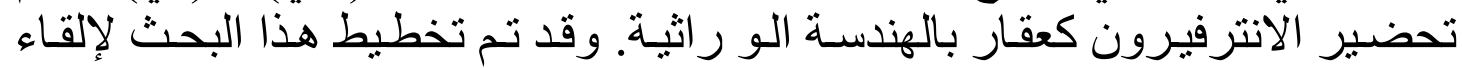

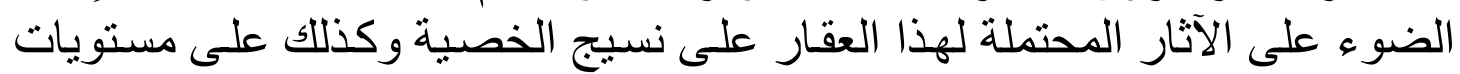

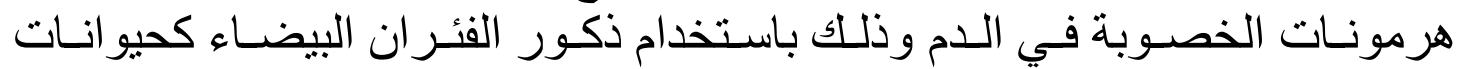

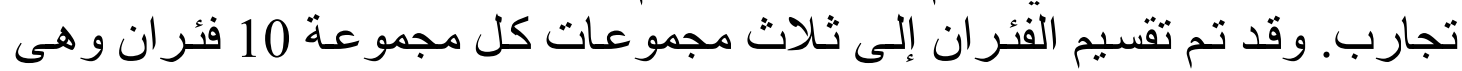
المجموعة الضابطة, المجموعة الاختبارية أعطيت عقار الانترفيرون (3000 وحدة

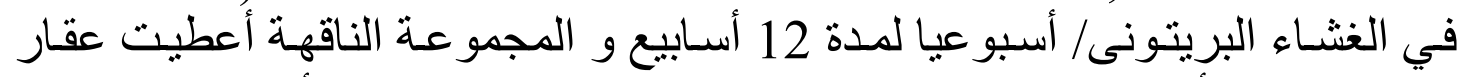

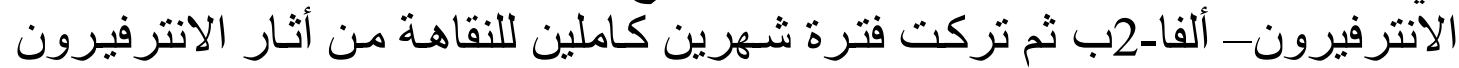

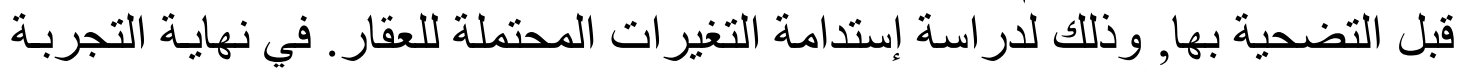

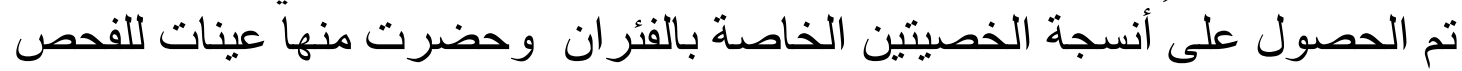

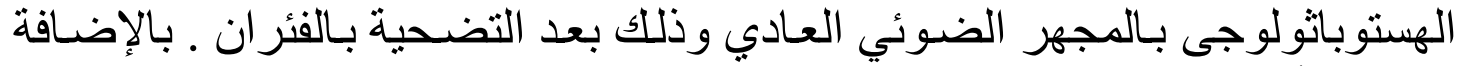

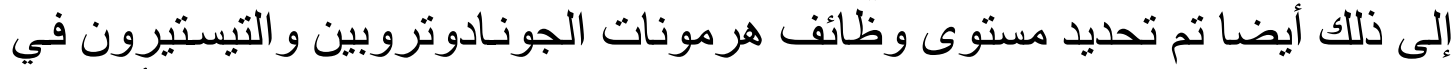

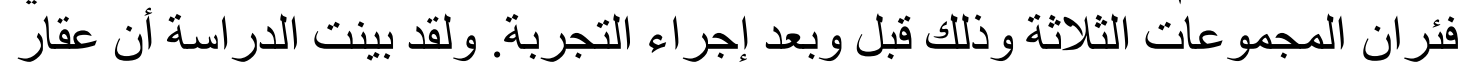

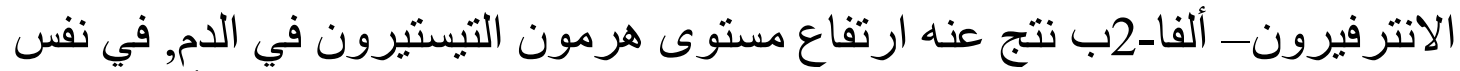

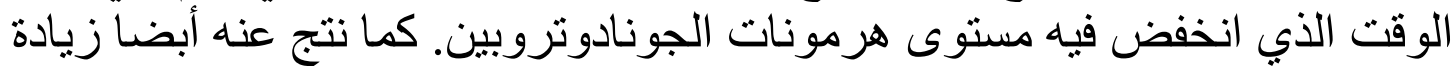

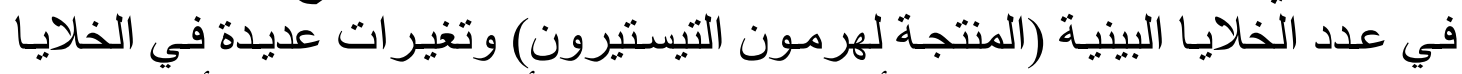

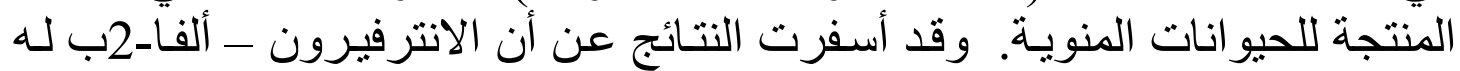

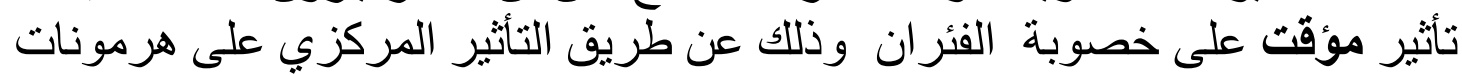

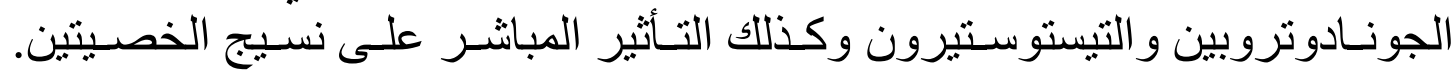

